\title{
DÜBLIN
}

Technological University Dublin

ARROW@TU Dublin

\section{Efficacy of Steamer Jet-Injection as Alternative to Chlorine in Fresh-Cut Lettuce}

\author{
Ana Belen Martin-Diana \\ Technological University Dublin, anabelen.martindiana@tudublin.ie \\ Daniel Rico \\ Technological University Dublin, daniel.rico@tudublin.ie \\ Catherine Barry-Ryan \\ Technological University Dublin, Catherine.Barryryan@tudublin.ie
}

See next page for additional authors

Follow this and additional works at: https://arrow.tudublin.ie/schfsehart

Part of the Food Microbiology Commons

\section{Recommended Citation}

Martin-Diana, A. et al. (2007) Efficacy of steamer jet-injection as alternative to chlorine in fresh-cut lettuce. Postharvest Biology and Technology, Vol. 45, Issue 1, July 2007, Pages 97-107 DOI: 10.1016/

j.postharvbio.2007.01.013

This Article is brought to you for free and open access by the School of Food Science and Environmental Health at ARROW@TU Dublin. It has been accepted for inclusion in Articles by an authorized administrator of ARROW@TU

Dublin. For more information, please contact arrow.admin@tudublin.ie, aisling.coyne@tudublin.ie, gerard.connolly@tudublin.ie.

Funder: Technological Sector Research grant (2002-2006) and International Collaboration Award Scheme (ICAS) (2005-2007)

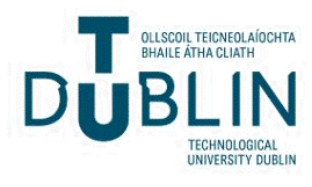




\section{Authors}

Ana Belen Martin-Diana, Daniel Rico, Catherine Barry-Ryan, Jesus Maria Frias, Gary Henehan, and J. Barat

This article is available at ARROW@TU Dublin: https://arrow.tudublin.ie/schfsehart/83 


\title{
Efficacy of steamer jet-injection as alternative to chlorine in fresh-cut lettuce
}

Postharvest Biology and Technology 45 (2007) 97-107

\author{
A. B. Martin-Dianaa, D. Ricoa, \\ Catherine Barry-Ryan a, J.M. Friasa, G.T.M. Henehana \& J.M. Barat b,
}

\begin{abstract}
a School of Food Science and Environmental Health, Dublin Institute of Technology (DIT), Cathal Brugha, Dublin 1, Ireland b Institute of Food Engineering for Development, Department of Food Technology, Universidad Polit' cnica, Camino de Vera s/n, 46022 Valencia, Spain
\end{abstract}

\begin{abstract}
Short-time steam processing was used as an alternative to chlorine (100 mg L-1) in sanitising fresh-cut lettuce. Quality (pH, water content, colour, potential browning, browning-related enzymes and texture), safety (mesophilic counts) and antioxidant markers (ascorbic and carotenoids) were monitored in lettuce stored for 10 days at $4 . \mathrm{C}$. The steam treatment produced a shocking effect on lettuce metabolism, showing a significant $(\mathrm{p}<0.05)$ reduction in respiration (from day 3 to 7$)$ and a partial inactivation of browning-related enzymes. Both effects were reflected in a significant reduction of browning. From a safety point of view, steam treatment kept the mesophilic load as low as chlorine treatment, and significantly lowers than the water control. However, antioxidant content, especially ascorbic acid but also carotenoids in a lower degree, showed a reduction compared with chlorine-treated samples. Despite the lower visual browning in steam-treated samples, the sensory panel scored similar values of acceptability and fresh appearance for both samples similarity.
\end{abstract}

Keywords: Shelf-life; Steamer; Chlorine; Quality; Antioxidant; Browning; Fresh-cut lettuce

\section{Introduction}

Fruit and vegetable consumption has grown over the last few years for a number of reasons. In general, consumers are more concerned about staying healthy and eating correctly, and research into nutraceuticals and functional food has highlighted the health compounds found in fruits and vegetables. Vegetables constitute a food source of carbohydrates, vitamins, proteins, fibers, i.e. leafy vegetables in particular are a rich source of antioxidants such as beta-carotene and ascorbic acid (Arthey and Dennis, 1992; Negi and Roy, 2000).

Associated with the new consumers profiles "rich in cash and poor in time", there is a demand for ready to eat products. For this reason the market of ready-to-use fresh vegetables have grown rapidly in recent decades as a result of changes in consumer attitudes (An Bord Glas, 2004). Lettuce is one of the most popular vegetables, and this is probably due to its crispness and attractive yellow-green colour.

However, this market of fresh-cut vegetables is limited by their short shelf-life and their rapid decline in post-processing quality and tissue browning is one of the major causes of loss in quality (Watada and Qui, 1999; Brecht, 1995).

Chlorine solutions have been widely used to sanitise freshcut fruits and vegetables in the industry because is very cheap, easy to use and very effective. However, the possible formation of carcinogenic chlorinated compounds in water has called into question the use of chlorine in food processing plants (Wei et al., 1995; Dychdala, 1991; Page et al., 1976).

Application of heat treatment is the most utilized method for stabilising foods not involving any chemical, because of its capacity to destroy microorganisms and inactivate enzymes. However, since heat can impair many organoleptic properties of foods and reduce the contents or bioavailability of some nutrients, there is a growing interest in searching for new technologies able to reduce the intensity of the damage for food preservation.

Low temperature blanching (heat-shock) alone or combined with other agents (Martin-Diana et al., 2005a,b; Saltveit, 2000) has been used to prevent browning reactions in fresh-cut lettuce. 
Firming effects obtained from heat treatments alone in lettuce have been attributed to the action of heat-activated pectin methylesterase (PME) and/or to increased diffusion into tissues at higher temperatures (Bartolome and Hoff, 1972; Garcia et al., 1996). The use of heat-shock is reported to enhance the bactericidal effect of sanitisers (Delaquis et al., 1999; Baur et al., 2005; Martin-Diana et al., 2005a). Nevertheless sanitising without any bactericidal solutions have been questioned, as it is unlikely to totally eliminate all pathogens from contaminated produce (Parish et al., 2001).

The use of blanching as decontaminate constitutes an unquestionable operation in the vegetables processing industries (Arroqui et al., 2003). The use of blanching (water or steam) not involving any chemical treatment can reduce initial mesophilic counts of leaf salads by more than three orders of magnitude and Enterobacteriaceae counts to less than $1 \mathrm{CFU} \mathrm{kg-1}\left(\mathrm{G}^{*}\right.$ rtnera et al., 1997). However, blanching itself introduces deleterious changes in the product by the loss of nutrients through thermal degradation, diffusion and leaching, increases the power consumption and generates effluents (Negi and Roy, 2000; Song et al., 2003). The objective of this paper is compare the effectiveness of a steamer (high temperature and short time) with chlorine by means of markers (quality, safety and antioxidant) directly or indirectly on the shelf-life of fresh-cut lettuce.

\section{Materials and methods}

\subsection{Sampling and experiment design}

The experiments were carried out between June and August 2005. Three replicates of the experiment were conducted with independent batches of lettuce. For colour and texture analyses all pieces in the assigned bag (20-25 approximately) were analysed individually to minimise error due to the product variability. For sensory analysis samples from the whole storage bag were analysed. For destructive analysis (enzymes, ascorbic acid, carotenoids, $\mathrm{pH}$, dry matter and microbiology) samples were taken from a pool of all the pieces in a storage bag.

\subsection{Processing and experimental set-up}

Iceberg lettuce (Lactuca sativa sp.) was grown in Valencia (Spain) and purchased from a local grower. The lettuce was brought to the laboratory within $12 \mathrm{~h}$ after the harvest and stored at $4 . \mathrm{C}$ before processing. Two treatments were compared. The samples were sanitised with chlorine (120 ppm) and blanching using a steamer jet-injection for $10 \mathrm{~s}$, according with the results of optimisation previously developed in our laboratory (Rico et al., 2007b). The two outer leaves were removed by hand and the core was excised with a stainless steel knife. The remaining head of lettuce was cut into halves and each half was further cut into six pieces. The temperature in the processing plant was $25 \circ \mathrm{C}$.

Chlorinated water was prepared by adding sodium hypochlorite solution ( $\geq 120 \mathrm{~g} / \mathrm{L}$ available chlorine) to distilled water to obtain $120 \mathrm{mg} / \mathrm{L}$ free chlorine $(\mathrm{pH} \sim 8)$. The solution was prepared using distilled water stored at room temperature $(25 \circ \mathrm{C})$. Treatments were carried out in different baskets with $\sim 200 \mathrm{~g} / \mathrm{L}$ of vegetable product immersed in solution for 1 min with agitation and subsequently dried for 5 min using an automatic salad spinner.

Blanching was carried out in a metal chamber $(60 \mathrm{~cm} \times$ $50 \mathrm{~cm} \times 20 \mathrm{~cm}$ ) fitted with a steam spreader at the bottom and open to the atmosphere on the opposite side (Fig. 1). The freshcut lettuce was placed on a supporting aluminium basket that allowed the steam to reach both sides of the fresh-cut lettuce bed. The rate of the steam was fed at a constant a rate of approximately $5.56 \times 10-4 \mathrm{~kg} \mathrm{~s}-1$. The blanching temperature was monitored and kept constant during the whole procedure $(100 \circ \mathrm{C})$. After blanching the product was immersed in water (room temperature $\sim 25 \circ$ C) for $1 \mathrm{~min}$ with agitation and subsequently dried for 5 min using an automatic salad spinner.

To minimise product heterogeneity, processed vegetables were pooled, mixed and subsequently packaged in bags $(200 \mathrm{~mm} \times 320 \mathrm{~mm})$ of $35 \mathrm{~m}$ oriented polypropylene (OPP) (Amcor Flexibles Europe-Brighouse, United Kingdom). The permeability of the film was with oxygen and carbon dioxide transmission rates of (1.37 and 1.49) $\times 10-9 \mathrm{~L} \mathrm{m-2} \mathrm{s}-1 \mathrm{~Pa}-1$ at $5 \circ \mathrm{C}$, respectively. Each package contained $\sim 100 \mathrm{~g}$ of product. The packages were chilled in a blast freezer at $0 \circ \mathrm{C}$ for $2 \mathrm{~min}$ before heat-sealing under atmospheric conditions. The final processed product was stored for 10 days at $4 \circ \mathrm{C}$.

\subsection{Shelf-life analysis}

Shelf-life is defined as the length of time which the vegetable can maintain the appearance, safety and antioxidant value that appeals to the consumer (Delaquis et al., 1999). For that reason the analyses of quality (headspace, dry matter, $\mathrm{pH}$, colour changes, texture and sensory analysis), microbial (mesophilic) and antioxidant (ascorbic acid and carotenoids) markers were monitored throughout the entire storage (10 days).

\subsubsection{Quality markers}

2.3.1.1. Headspace composition. A Gaspace analyser (PBI Dansensor, model CheckMate 9900, Ringsted, Denmark) was used to monitor levels of $\mathrm{CO}_{2}$ and $\mathrm{O}_{2}$ during storage. Gas extraction was performed with a hypodermic needle, inserted through an adhesive septum previously fixed to the bag, at a flow rate of $25 \mathrm{~L} \mathrm{~s}-1$ for $1 \mathrm{~min}$, monitoring with a sensitivity of 0.001 $\left(\mathrm{O}_{2}\right)$ and $0.1\left(\mathrm{CO}_{2}\right)$. The accuracy is in percentage of readings: $\pm 1 \%$ of the reading in the calibrated range and $\pm 2 \%$ of the full range for $\mathrm{CO}_{2}$. Three bags per treatment were monitored for each experiment and the rest of bags used for other analyses were also measured.

2.3.1.2. Dry matter. A weighed piece of lettuce was heated at $100 \cdot \mathrm{C}$ for $2 \mathrm{~h}$ in a Universal Oven (Memmert, Schwabach, Germany). Dry matter was calculated using the weight after heating as a percentage of the initial weight.

2.3.1.3. $\mathrm{pH}$ measurement. Ten-gram sample of vegetable tissue was blended for $2 \mathrm{~min}$ in $20 \mathrm{~mL}$ of deionised water. The $\mathrm{pH}$ of the slurry was measured at room temperature using a research 


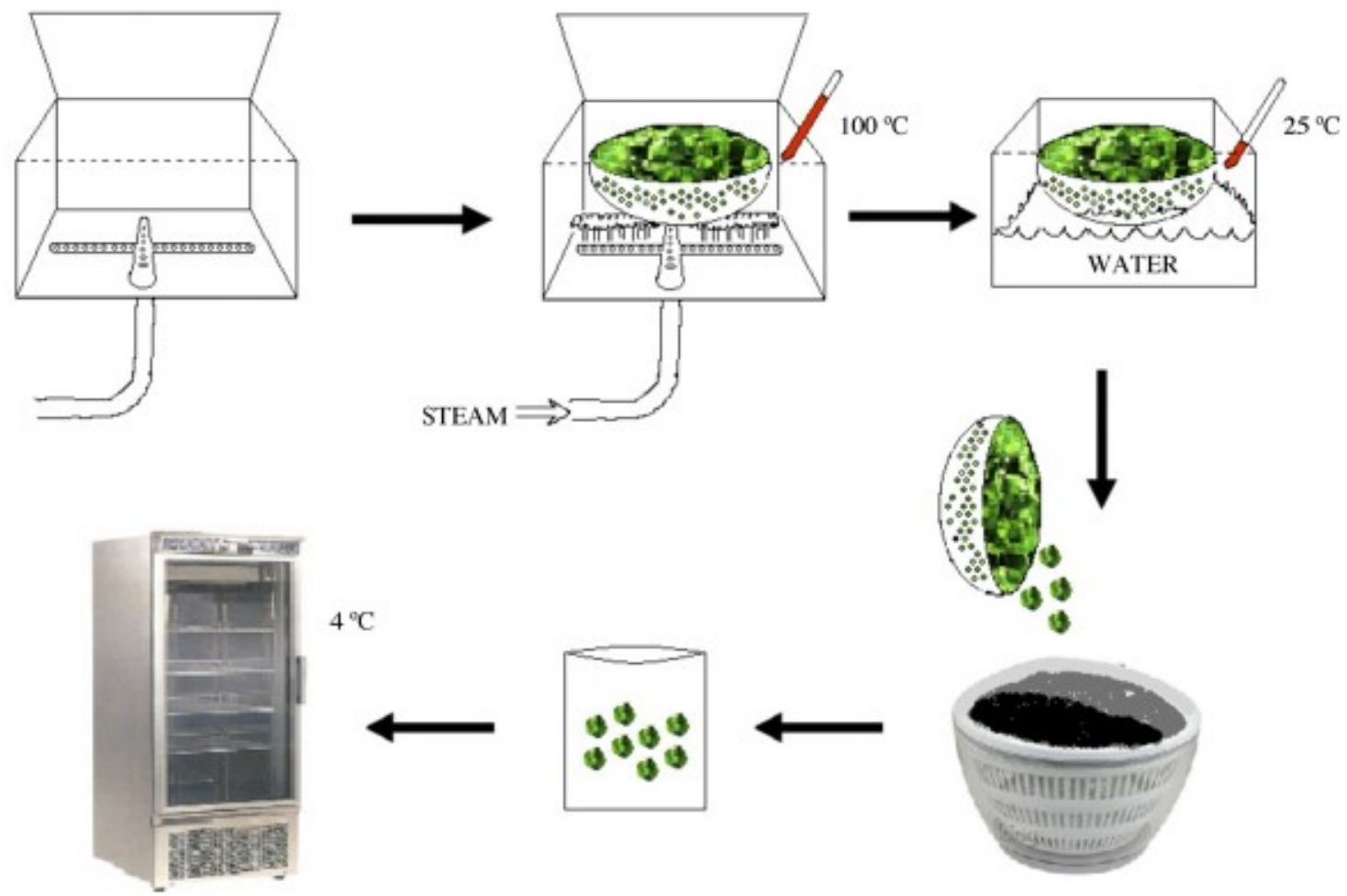

Fig. 1. Experimental set-up to steam fresh-cut lettuce.

pH-meter (Consort, model C830, Turnhout, Belgium) between 18 and $20 \cdot \mathrm{C}$.

\subsubsection{Browning-related enzymes: peroxidase (POD)} E.C.1.11.1.7 and polyphenol oxidase (PPO) E.C.1.10.3.1. Both enzymes were assayed in homogenates prepared as follows: $10 \mathrm{~g}$ of vegetable was placed in a UltraTurrax homogeniser (Ika-Labortechnik, model UltraTurrax T25, Stanfen, Germany) in a $1: 2(\mathrm{w}: \mathrm{v})$ ratio with $0.5 \mathrm{M}$ phosphate buffer $\mathrm{pH} 6.5$ containing $50 \mathrm{~g} / \mathrm{L}$ polyvinylpyrrolidone. Homogenisation was carried out two times at $4 . \mathrm{C}$, and $91.67 \mathrm{~s}-1$, for $1 \mathrm{~min}$ each time with a break of 3 min between homogenisations in order to avoid excess heating of the sample. The homogenate was then centrifuged at $12,720 \times \mathrm{g}$ for $30 \mathrm{~min}$ at $4 . \mathrm{C}$ and supernatant filtered through one layer of crepe bandage. The resulting crude extract was used without further purification. All the extracts were stored at $4 . \mathrm{C}$ in the dark and used immediately.

PPO activity was assayed spectrophotometrically (Thermo electron corporation, model CE 1020, Madrid, Spain) by a modified method based on Galeazzi et al. (1981) and Tan and Harris (1995). The reaction mixture contained $0.1 \mathrm{~mL}$ crude extract and $2.9 \mathrm{~mL}$ substrate solution $(0.02 \mathrm{~mol} / \mathrm{L}$ catechol in $0.05 \mathrm{~mol} / \mathrm{L}$ phosphate buffer, $\mathrm{pH}$ 6.5). The rate of catechol oxidation was followed at $400 \mathrm{~nm}$ for $2 \mathrm{~min}$ at $25 \circ \mathrm{C}$. An enzyme activity unit was defined as an increase of 0.1 in absorbance per minute. The reaction mixture contained $0.2 \mathrm{~mL}$ of extract and $2.7 \mathrm{~mL}$ of $0.05 \mathrm{M}$ phosphate buffer $\mathrm{pH} 6.5$ containing $100 \mathrm{~L}$ of hydrogen peroxide $(1: 1000, \mathrm{v}: \mathrm{v})$ as oxidant and $200 \mathrm{~L}$ of p-phenylendiamine as hydrogen donor. The oxidation of $\mathrm{p}$-phenylendiamine was monitored at $485 \mathrm{~nm}$ and $25 \circ \mathrm{C}$. An enzyme activity unit was defined as an increment of 0.1 in absorbance per minute.

2.3.1.5. Potential browning. Potential browning was measured according with the methodology of $\mathrm{Vi}^{\longleftarrow}$ a and Chaves (2006). Tenn grams of tissue frozen and crushed were treated with ethanol $96 \cdot \mathrm{C}$ for $60 \mathrm{~min}$ and then centrifuged at $100 \mathrm{~s}-1$ at $10 \cdot \mathrm{C}$ for $10 \mathrm{~min}$ retaining the supernatants. After a further amount of ethanol was added to complete the final volume to $25 \mathrm{~mL}$. Absorbance at $320 \mathrm{~nm}$ was measured on aliquots of this extracts. The results were expressed as absorbance units (AU) per kilogram of fresh tissue.

2.3.1.6. Colour measurement. Colour was quantified using a colorimeter (Minolta, Model CM-3600d, United Kingdom). A lettuce piece was place directly on the colorimeter sensor (3.5 $\times 10-2 \mathrm{~m}$ of diameter) and measured; $20-30$ measurements were taken per treatment and day. The instrument was calibrated using a white tile $\left(\mathrm{L}^{*}=93.97, \mathrm{a}^{*}=-0.88\right.$ and $\left.b^{*}=1.21\right)$ and a green tile $\left(L^{*}=56.23, a^{*}=-21.85, b^{*}=8.31\right)$ standards. The $L^{*}$ parameter (lightness index scale) range from 0 (black) to 100 (white). The $a^{*}$ parameter measures the degree of red $(+a)$ or green $\left(-a^{*}\right)$ colour and the $b^{*}$ parameter measures the degree of yellow $(+b)$ or blue $\left(-b^{*}\right)$ colour. The CIE $L^{*} a^{*} b^{*}$ parameters were converted to Hue $\left(\arctan b^{*} / a^{*}\right)$, Chroma $\left(a_{2}+b_{2}\right) 1 / 2$ and total colour difference $\left(E=\left[\left(L_{f}-L_{i}\right) 2+(a f-a i) 2+\left(b f-b_{i}\right) 2\right] 1 / 2\right)$, where $L_{i}$, initial luminosity; $\mathrm{Lf}$, final luminosity; $a f, a^{*}$ value at final time; $a_{i}, a^{*}$ value at initial time; $b_{f}, b^{*}$ at final time; $b_{i}$, the value $b^{*}$ at initial time. 
2.3.1.7. Digital analysis. Images of the lettuce were captured using a digital (Canon Power Shot, CCD 3.1 MPixels, Japan). The camera was set to 1.0 digital zoom on automatic indoor focus with the flash turned off. A lighting unit with two fluorescent lamps provided the only illumination in a dark room in order to obtain images with the same brightness and contrast (Kaiser Fototechnik, RB 5000 DL Copy Lighting Unit 5556, Buchen, Germany). These settings provided a close up view of the lettuce and covered the entire field of view. This picture was saved as a JPEG. The stored digital images were analysed for RGB changes using an image analysis program (Photoshop ${ }^{\circledR}$ image Adobe System, 2002 software).

Three packages of lettuce were photographed for each treatment. Lettuce treatments were assessed four times during the experiment at $1,3,7$, and 10 days, respectively, after the lettuce were processed and packaged.

2.3.1.8. Texture analysis. Texture properties of lettuce were assessed using an Aname texture analyser (Stable Micro Systems, model TA.XTPlus, London, United Kingdom). A $500 \mathrm{~N}$ load cell was attached. For lettuce a shear cell (Flexion-Fracture) with a blade probe attached to the instrument was used. The speed setting for the experiment was 1.67 (mm s-1) and maximum load was reported $(\mathrm{kN} / \mathrm{kg})$. The instrumental measurement of lettuce texture is difficult to carry out, due mainly to the high variability of the product. Values were expressed as the coefficient ((max load - min load)/max load) which was defined as the crispiness coefficient (CC) (Martin-Diana et al., in press). More than 25 samples were analysed per treatment and day.

2.3.1.9. Sensory analysis. Analytical-descriptive tests were used to evaluate the sensory quality attributes of fresh-cut lettuce prepared by different washing treatments. The panel, which consisted of 12 judges aged 22-35 years ( 8 females and 4 males, all members of the University Polytechnic of Valencia) with sensory evaluation experience, were trained in discriminate evaluation of fresh-cut lettuce. Panellists were required to score changes in fresh appearance, photosynthetic browning, vascular browning and general acceptability. Before the start of the sensory experiments, panel members were familiarised with the product and scoring methods. This consisted of demonstration exercises involving examination of packs at different levels of deterioration and agreeing appropriate scores. When the panel members had become familiar with the test facilities and scoring regime, they were invited to score samples. This procedure was repeated several times until a level of consistency in scoring was obtained.

The same packages were scored during the entire test for sensory analysis (10 days), due to the high variability of the product. During this stage, the samples were presented to the panel to evaluate and measure the reproducibility of the judges answer and their capability in discriminating among samples. During the analyses, samples were presented in randomized order to minimize possible carry-over effects.

Fresh-cut was evaluated for appearance using a five point numerical rating scale, where a score of 5 indicated the sample was: (I) fresh appearance, where $1=$ very good/fresh appearance,
$3=$ moderate, and $5=$ poor/no fresh appearance; (II) photosynthetic browning, where $1=$ nothing, $3=$ moderate and $5=\mathrm{a}$ lot (severe browning); (III) vascular browning, where 1 = nothing, $3=$ moderate and $5=\mathrm{a}$ lot (severe browning); (IV) general acceptability, where $1=$ very good, $3=$ moderate and $5=$ very bad.

Sensory evaluation was used to determine the shelf-life of these products, as scores equal to or below 3 was taken as unacceptable, and to indicate the end of shelf-life. The results of the sensory analysis were reported as means of three separate trials. Data analysis was collected using Compusense ${ }_{\circledast}$ Five software (Release 4.4, Ontario, Canada).

\subsubsection{Safety markers}

2.3.2.1. Mesophiles. Microbiological analyses were carried out on the samples before and after the treatment at regular intervals through the storage period (days $0,1,3,7$ and 10). Twenty-five grams of vegetable were blended in $225 \mathrm{~mL}$ of peptone saline with a Stomacher circulator homogenizer. A total count enumeration was carried out as at $30 \cdot \mathrm{C}$ on plate count agar (PCA) incubated for $72 \mathrm{~h}$. The results were expressed as $\log 10$ colony forming units per kg (CFU kg-1). Due to the huge variability for the leafy products (lettuce) the samples for microbiological assays were taken from the top part of the head of the lettuce.

\subsubsection{Antioxidant markers}

2.3.3.1. Ascorbic acid. Ascorbic acid determination was carried out according to the 2,6-dichlorolindophenol method recommended by AOAC (1995) for the analysis of vitamin C in fruits and juices. The amount of ascorbic acid per sample was expressed as gram per kilogram.

The methodology consisted in $20 \mathrm{~g}$ of fresh-cut was homogenised with $50 \mathrm{~mL}$ of acetic-metaphosphoric acid at low speed (in order to avoid foaming) for $3 \mathrm{~min}$ at $4 . \mathrm{C}$ in darkness. The homogenate was filtered and acetic-metaphosphoric added to $100 \mathrm{~mL}$. Aliquots of $10 \mathrm{~mL}$ were titrated rapidly in triplicate, using acetic-metaphosphoric acid as a blank. The results were expressed as gram of ascorbic acid in kilogram of sample:

$$
\frac{\text { g ascorbic acid }}{\text { kg sample }}=\left(\begin{array}{lll}
X-B) & F & \text { F }
\end{array}\right.
$$

where $\mathrm{X} \mathrm{mL}$ 2,6-dichlorolindophenol is used to obtain permanent colour more than $5 \mathrm{~s}$; $\mathrm{B}$ is the volume used for the control (blank); $\mathrm{F}$ the 2,6-dichlorolindophenol factor (calculated with a standard of $2 \mathrm{~g} / \mathrm{L}$ ascorbic acid); $\mathrm{E}$ the $\mathrm{kg}$ of sample used in the assay; $\mathrm{V}$ the final volume used $(0.1 \mathrm{~L}) ; \mathrm{Y}$ is the volume of the aliquot titrated $(10 \mathrm{~mL})$.

2.3.3.2. Carotenoids. Total carotenoids were extracted in dark conditions by homogenizing lettuce tissue $(5 \mathrm{~g})$ with $30 \mathrm{~mL}$ of an acetone/ethanol (50:50, v:v) solution, containing $200 \mathrm{mg} / \mathrm{L}$ of butylated hydroxytoluene (BHT). The homogenate was filtered and washed with acetone/ethanol solvent until colourless. Filtrate was adjusted to $100 \mathrm{~mL}$ volume with acetone/ethanol. An aliquot was placed in a $1 \mathrm{~cm}$ cuvette and its absorbance measured at $470 \mathrm{~nm}$ in a spectrophotometer (Thermo electron 
corporation, model CE 1020, Madrid, Spain). Total carotenoids (g/kg of sample) were calculated as described by Gross (1991).

\subsection{Statistical analysis}

Analysis of ANOVA (multifactor and one-way) were used to find differences between treatments, storage and interaction of both factors for each one of the variables studied. Means were compared by significant difference (L.S.D.) test, at a significance level $p=0.05$ using the Statgraphics software (Version 2.1; Statistical Graphics Co., Rockville, USA). Three independent trials were carried out.

\section{Results and discussion}

The effectiveness of the steamer compared with chlorine was measured using a group of markers (quality, safety and antioxidant capacity) which gave information about the shelf-life stage of the fresh-cut lettuce over the storage.

\subsection{Quality markers}

\subsubsection{Headspace}

Headspace composition was monitored in the bags through the entire storage. Fig. 2 shows the changes in oxygen (I) and carbon dioxide (II) headspace levels for fresh-cut lettuce treated with chlorine and/or steamer. Oxygen significantly $(\mathrm{p}<0.05)$ decreased from the initial atmospheric concentration (21\%) to values close to $18 \%$ after the first day of storage without differences between treatments. This decrease in oxygen reflected the increase of respiration rate caused by the stress of the minimal procedures on the vegetable (Surjadinata and Cisneros-Zevallos (2003)). After day 1 oxygen levels decreased at a slower pace, however, from days 3 to 10 samples treated with chorine showed significantly $(p<0.05)$ higher oxygen consumption than samples treated with steam. This reduction in the consumption of oxygen in steamed samples could be due to a shocking effect of the temperature on the vegetable, which might produce a decrease in the respiration rate. There is a lack of published information on the effects of blanching on respiration. Odumeru
Table 1

Effect of storage and treatment (chlorine and steamer) on $\mathrm{pH}$ and water content $(\%)$ in fresh-cut lettuce stored at $4 \cdot \mathrm{C}$ for 10 days

\begin{tabular}{|c|c|c|c|}
\hline Storage (days) & Treatment & $\mathrm{pH}(\mathrm{ChlB}, \mathrm{StmA})$ & $\begin{array}{l}\text { Water content }(\%) \\
(\mathrm{ChlB}, \mathrm{StmA})\end{array}$ \\
\hline 1 & $\begin{array}{l}\text { Chlorine } \\
\text { Steamer }\end{array}$ & $\begin{array}{l}6.44 \pm 0.060 \mathrm{c} \\
5.89 \pm 0.052 \mathrm{a}\end{array}$ & $\begin{array}{l}96.91 \pm 0.244 b \\
97.18 \pm 0.174 b\end{array}$ \\
\hline 3 & $\begin{array}{l}\text { Chlorine } \\
\text { Steamer }\end{array}$ & $\begin{array}{l}6.49 \pm 0.065 d \\
6.11 \pm 0.046 b c\end{array}$ & $\begin{array}{l}96.67 \pm 0.210 \mathrm{ab} \\
97.17 \pm 0.230 \mathrm{~b}\end{array}$ \\
\hline 7 & $\begin{array}{l}\text { Chlorine } \\
\text { Steamer }\end{array}$ & $\begin{array}{l}6.55 \pm 0.046 \mathrm{~d} \\
6.40 \pm 0.047 \mathrm{c}\end{array}$ & $\begin{array}{l}96.39 \pm 0.204 \mathrm{a} \\
97.30 \pm 0.218 \mathrm{~b}\end{array}$ \\
\hline 10 & $\begin{array}{l}\text { Chlorine } \\
\text { Steamer }\end{array}$ & $\begin{array}{l}6.38 \pm 0.042 \mathrm{c} \\
6.53 \pm 0.035 \mathrm{~d}\end{array}$ & $\begin{array}{l}96.63 \pm 0.235 \mathrm{a} \\
96.22 \pm 0.257 \mathrm{a}\end{array}$ \\
\hline
\end{tabular}

Each value represents mean and standard deviation. Values followed by different lower case letters in the same row indicate significant differences during storage. Upper case letters indicate differences between treatments (chlorine$\mathrm{Chl} /$ steamer-Stm). Three independent trials were carried out. Three replicates per treatment and per batch were analysed.

et al. (2003) found similar findings in lettuce treated with warm water, however McKellar et al. (2004) found opposite results. At the end of the storage both treatments reached similar oxygen values $(8-9.6 \%)$.

As expected, carbon dioxide (Fig. 2II) showed an inverse pattern to oxygen, increasing significantly $(\mathrm{p}<0.05)$ during storage, reaching final concentrations of around $7 \%$, avoiding hypoxic atmosphere conditions which favour the fermentative processes that cause the formation of acetaldehyde and the appearance of off-flavours compounds (Kays, 1991).

\subsubsection{Water content}

Fresh-cut lettuce is very susceptible to moisture loss and consequently to weight loss. However, the relative humidity is generally very high inside the bags, so dehydration is not a common problem when the vegetables are packaged (Watada and Qui, 1999). Since the loss of water content is an indicator of quality retention, this was monitored during storage for the fresh-cut lettuce. A significant $(p<0.05)$ decrease in water was observed during the storage in both samples $(p>0.05)$, with significant differences between treatments (Table 1). Samples treated with
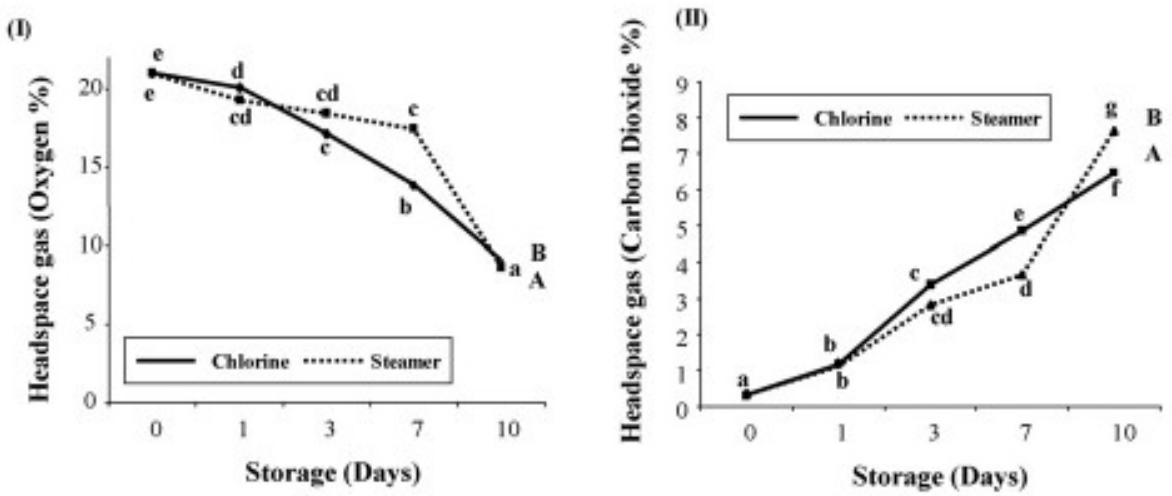

Fig. 2. Package headspace content (oxygen (I) and carbon dioxide (II) concentration (\%)) as a function of treatment (chlorine and steamer) and storage time (10 days) on fresh-cut lettuce. *Points designated on any curve by the same letter are not significantly different ( $p>0.05)$. Lower case letters are used for comparisons during storage and upper case letters for treatment comparisons. Three independent trials were carried out. Three bags per treatment and per batch were monitored during all the storage. 
the steamer showed higher content of water than samples treated with chlorine from day 3 to 7 , reaching similar values at day 10 . This water loss responds to the natural catabolism process in vegetable commodities, catalysed by enzymes and accelerated by the minimal processing (Ihl et al., 2003). According to Ryall and Lipton (1972) more than 5\% water loss can cause rejection of samples due to the textural breakdown in lettuce. In this case water loss increased significantly $(p<0.05)$ during storage, but with no significant differences $(\mathrm{p}<0.05)$ between treatments. The samples showed water losses lower than $5 \%$ (Table 1).

\subsection{3. $\mathrm{pH}$}

Samples treated with chlorine showed highest $\mathrm{pH}$ values from day 1 to 10 than samples treated with the steamer (Table 1). This could be due to the inhibitory effect of temperature on bacterial growth. Delaquis et al. (1999) and Beuchat and Brackett (1990) have described a reduction in bacterial counts in lettuce treated with hot water. However differences in microbiological loads were not observed (Fig. 3) between the lettuce treated with chlorine or the steamer.

\subsubsection{Browning-related enzymes}

PPO and POD activity varied $(\mathrm{p}<0.05)$ depending on the tissue, especially in the case of the PPO, with values in photosynthetic tissues two- to four-fold the values of vascular tissues. Other authors also found higher PPO and POD activity in photosynthetic tissues than in vascular tissues (Martin-Diana et al., 2005a,b; Heimdal et al., 1994; Vamos-Vigyazo, 1981). These findings attributed the higher activity in photosynthetic tissue to the location of the PPO and POD in the thylakoid membrane of the chloroplasts. In our experiments, both tissues were studied separately to reduce heterogeneity, naturally high due to the variability of the lettuce and pre- and post-harvest factors such as produce cultivation or handling (Sam, 1999; Lee and Kader, 2000).

Table 2 shows POD values for chlorine and the steamer treatments. Steam treatment dramatically reduced POD activity compared with chlorine $(0.283 \pm 0.037$ and $2.248 \pm 0.189$ Units kg-1, respectively; activity at day 1 ). However, $10 \mathrm{~s}$ of

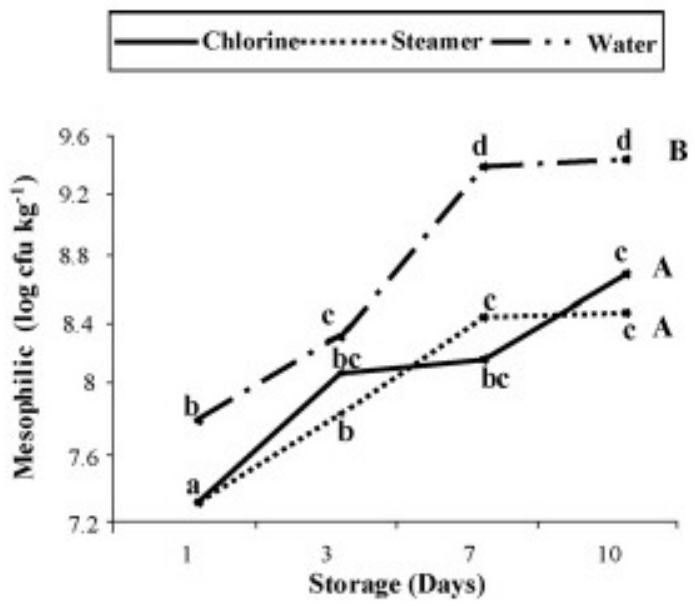

Fig. 3. Microbial load (mesophilic, log cfu kg-1) during storage of fresh-cut lettuce treated with water, chlorine and for steamer, stored for 10 days at $4 \circ \mathrm{C}$. *Points designated on any curve by the same letter are not significantly different $(\mathrm{p}>0.05)$. Lower case letters are used for comparisons during storage and upper case letters for treatment comparisons. Three independent trials were carried out. Three replicates per treatment and per batch were analysed.

steam treatment was not long enough to completely inactivate the POD. A significant $(\mathrm{p}<0.05)$ increase in the activity in both samples was observed during storage mostly in the photosynthetic tissues. By the end of the storage, the POD activity levels remained lower in the steam-treated than in the chlorine-treated samples, and these differences were more marked in vascular tissue.

This regeneration of POD activity after heat treatment was reported by some researchers in model conditions (Adams et al., 1996; Rodrigo et al., 1997).

Polyphenol oxidase activity was also analysed over the storage (Table 2). A similar behaviour to the POD was observed, and the PPO activity showed higher values in chlorinated samples compared with blanched samples.

The differences in both enzymes activities due to the treatment are significant from day 1 , showing a probable effect of the temperature on the inactivation of the enzymes. Although the inactivation was not complete the temperature treatment

Table 2

Effect of storage and treatment (chlorine and steamer) on peroxidase (POD) and polyphenol oxidase (PPO) activity [Units kg-1 ] in fresh-cut lettuce stored at $4 . \mathrm{C}$ for 10 days

\begin{tabular}{|c|c|c|c|c|c|}
\hline \multirow[t]{2}{*}{ Storage (days) } & \multirow{2}{*}{ Treatment } & \multicolumn{2}{|l|}{ POD (Units kg-1) } & \multicolumn{2}{|l|}{ PPO (Units $\times$ kg-1) } \\
\hline & & Photo syntheticB (ChlB, StmA ) & VascularA (ChlB, StmA ) & PhotosyntheticB (ChlB, StmA ) & VascularA (ChlB, StmA ) \\
\hline 1 & $\begin{array}{l}\text { Chlorine } \\
\text { Steamer }\end{array}$ & $\begin{array}{l}2.248 \pm 0.189 \mathrm{e} \\
0.283 \pm 0.037 \mathrm{a}\end{array}$ & $\begin{array}{l}2.235 \pm 0.104 \mathrm{~d} \\
0.247 \pm 0.148 \mathrm{a}\end{array}$ & $\begin{array}{r}18.157 \pm 0.557 \mathrm{e} \\
2.039 \pm 0.436 \mathrm{a}\end{array}$ & $\begin{array}{l}5.549 \pm 0.271 \mathrm{e} \\
0.475 \pm 0.012 \mathrm{~b}\end{array}$ \\
\hline 3 & $\begin{array}{l}\text { Chlorine } \\
\text { Steamer }\end{array}$ & $\begin{array}{l}2.342 \pm 0.088 \mathrm{e} \\
0.376 \pm 0.022 \mathrm{~b}\end{array}$ & $\begin{array}{l}1.424 \pm 0.092 \mathrm{e} \\
0.199 \pm 0.040 \mathrm{a}\end{array}$ & $\begin{array}{r}15.403 \pm 0.177 \mathrm{~d} \\
2.564 \pm 0.596 \mathrm{a}\end{array}$ & $\begin{array}{l}4.221 \pm 0.797 \mathrm{~d} \\
0.373 \pm 0.035 \mathrm{a}\end{array}$ \\
\hline 7 & $\begin{array}{l}\text { Chlorine } \\
\text { Steamer }\end{array}$ & $\begin{array}{l}2.836 \pm 0.095 \mathrm{f} \\
0.954 \pm 0.030 \mathrm{c}\end{array}$ & $\begin{array}{l}3.461 \pm 0.441 \mathrm{f} \\
0.417 \pm 0.021 \mathrm{~b}\end{array}$ & $\begin{array}{l}23.392 \pm 0.511 \mathrm{f} \\
10.577 \pm 0.331 \mathrm{~b}\end{array}$ & $\begin{array}{l}8.812 \pm 0.533 \mathrm{f} \\
0.493 \pm 0.015 \mathrm{~b}\end{array}$ \\
\hline 10 & $\begin{array}{l}\text { Chlorine } \\
\text { Steamer }\end{array}$ & $\begin{array}{l}2.869 \pm 0.011 \mathrm{f} \\
1.407 \pm 0.174 \mathrm{~d}\end{array}$ & $\begin{array}{l}2.580 \pm 0.195 \mathrm{e} \\
0.432 \pm 0.021 \mathrm{~b}\end{array}$ & $\begin{array}{l}22.946 \pm 1.438 \mathrm{f} \\
11.420 \pm 0.505 \mathrm{c}\end{array}$ & $\begin{array}{l}9.176 \pm 0.669 \mathrm{f} \\
0.575 \pm 0.021 \mathrm{c}\end{array}$ \\
\hline
\end{tabular}

Each value represents mean and standard deviation. Values followed by different letters in the same row indicate significant differences during storage. Upper case letters indicate differences between treatments (chlorine-Chl/steamer-Stm) and upper case bold letters indicate differences between tissues (photosynthetic/vascular). Three independent trials were carried out. Three replicates per treatment and per batch were analysed. 

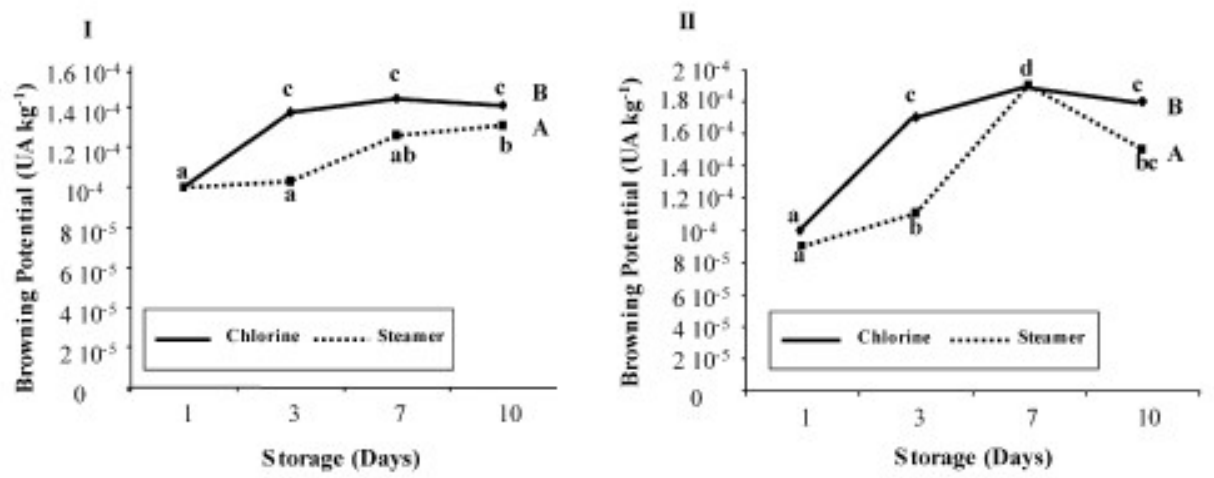

Fig. 4. Browning potential (absorbance units per kilogram of fresh tissue) of photosynthetic tissue (I) and vascular tissue (II) of fresh-cut lettuce treated with chlorine and steamer and stored 10 days at $4 . \mathrm{C}$. *Points designated on any curve by the same letter are not significantly different ( $\mathrm{p}>0.05)$. Lower case letters are used for comparisons during storage and upper case letters for treatment comparisons. Three independent trials were carried out. Three replicates per treatment and per batch were analysed.

kept enzymatic values lower than chlorine did during the whole storage (10 days).

\subsubsection{Potential browning}

Potential browning was monitored in all the samples. Significant increments through the storage and differences between treatments and tissues were found (Fig. 4). The potential browning was lower in photosynthetic tissue than in vascular, although the activity of browning-related enzymes was higher in the first than in the second. These differences can be caused by conditions favouring non-enzymatic browning. The browning in chlorinated samples was significantly higher than in steamer-treated samples, which was correlated with the enzymatic browning. So the reduction in steamer-treated samples could be due to the inactivation of the enzymes.

\subsubsection{Colour changes}

Changes in colour were measured with a colorimeter (Fig. 5) and the whole packages were monitored by digital image analysis (Fig. 6). Digital image analysis was used to measure differences in colour changes (RGB colour space and luminosity) of each treatment. The use of digital image analysis allows a more precise evaluation of the speed of browning appearance since the same bag is monitored throughout all the storage (10 days).

The colorimeter analyses showed a significant $(\mathrm{p}<0.05)$ decrease in luminosity observed for both treatments; this is expected to occur due to the appearance of browning (Fig. 5I). A significantly higher luminosity $(\mathrm{p}<0.05)$ was recorder for the samples treated with the steamer compared with those treated with chlorine. This could be due to the effect of light bleaching of the steam on the tissues. However, the levels of luminosity at the end of the storage were similar for vegetables treated with either treatment.

Noticeable significant $(\mathrm{p}<0.05)$ changes in green colour (Fig. 5II) were observed, as a result of degradation of green pigments (chlorophylls) accompanied with the appearance of browning. The lowest values of green were observed at days 7 and 10. These decreases in green colour were coupled with an increase in red colour responding to the browning appearance.
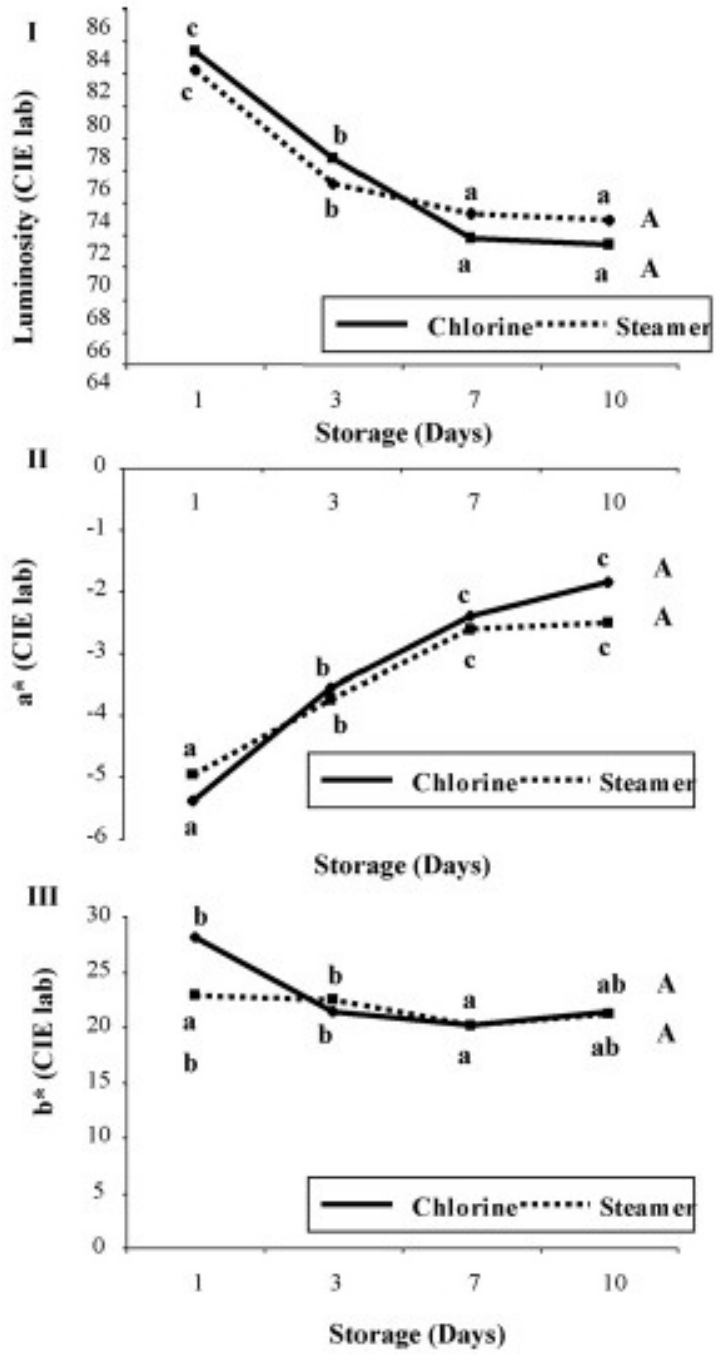

Fig. 5. CIE $L^{*} a^{*} b^{*}$ colour parameters obtained from colorimeter analysis of fresh-cut lettuce. Effect of treatment (chlorine and steamer) and storage time (1-10 days at $4 \circ C)$. *Points designated on any curve by the same letter are not significantly different $(\mathrm{p}>0.05)$. Lower case letters are used for comparisons during storage and upper case letters for treatment comparisons. Three independent trials were carried out. Three replicates per treatment and per batch were analysed. 

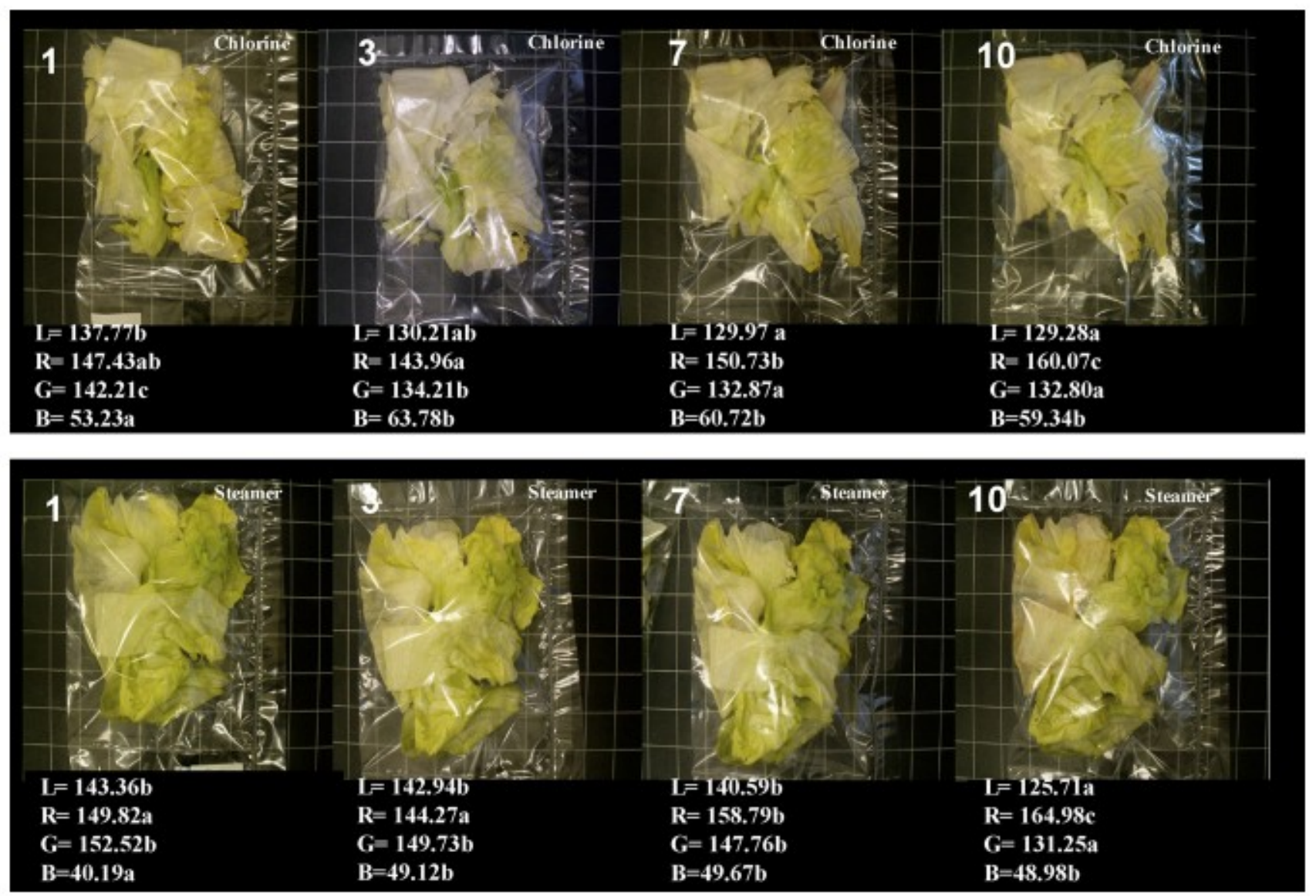

Fig. 6. Fresh-cut packaged lettuce treated with chlorine and steamer. Luminosity and RGB values obtained with digital image analysis. *Values designated by the same letter for each treatment during the storage are not significantly different $(\mathrm{p}>0.05)$. Three independent trials were carried out. Three replicates per treatment and per batch were analysed.

Differences between both treatments were not observed in red and green parameters.

Digital image analysis (Fig. 6) was used to obtain RGB values during storage. A significant decrease in luminosity was observed. The green colour decreased significantly $(\mathrm{p}<0.05)$ during storage for both treatments, meanwhile the red parameter increased. These results were in agreement with the colorimeter results. The chlorinated samples showed higher levels of the red parameter (an indicator of browning), and the difference between chlorinated sample and steamer samples were more evident at day 7 .

\subsubsection{Textural properties}

Significantly higher values $(\mathrm{p}<0.05)$ of $\mathrm{CC}$ were observed in samples treated with steamer compared with those treated with chlorine (Fig. 7). The steamer-treated samples showed higher maximum load values at the breaking point and $\mathrm{CC}$ values when measured after the treatment (day 1) and throughout the whole storage.

The beneficial effects on texture after thermal treatments have been explained in terms of the activation of pectin methyl esterase (PME) (Bartolome et al., 1972; Chang et al., 1996; Van Buren, 1979; Ni et al., 2005; Martin-Diana et al., 2005a, in press). Previous work in this laboratory showed calcium lac-

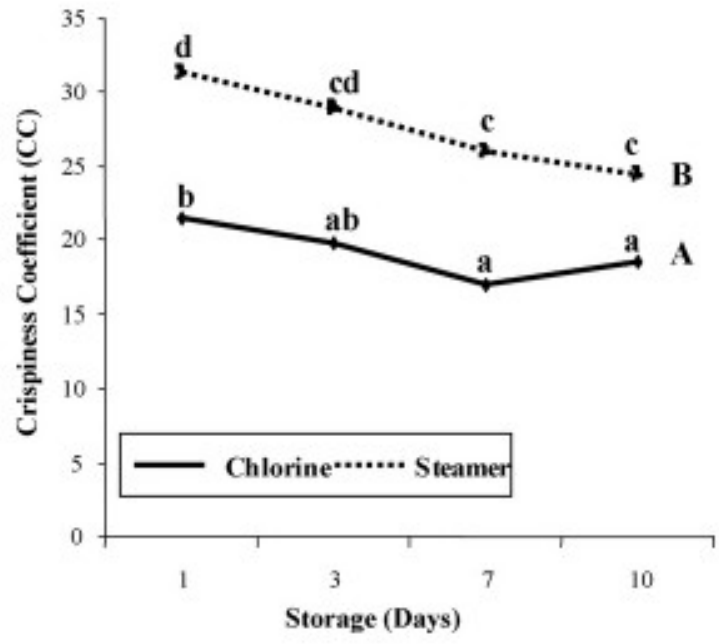

Fig. 7. Effect of treatment (chlorine and steamer) on the textural properties (coefficient of crispness (CC)). *Points designated on any curve by the same letter are not significantly different $(\mathrm{p}>0.05)$. Lower case letters are used for comparisons during storage and upper case letters for treatment comparisons. Three independent trials were carried out. Three replicates per treatment and per batch were analysed. 
Table 3

Sensory evaluation of fresh-cut lettuce treated with chlorine and steamer and stored for 10 days at $4 . \mathrm{C}$

\begin{tabular}{|c|c|c|c|c|c|}
\hline Storage (days) & Treatment & $\begin{array}{l}\text { Fresh appearance } \\
(\text { ChlA, StmA })\end{array}$ & $\begin{array}{l}\text { Photosynthetic browning } \\
\text { (ChlB, StmA ) }\end{array}$ & $\begin{array}{l}\text { Vascular browning } \\
\text { (ChlB, StmA ) }\end{array}$ & $\begin{array}{l}\text { General acceptability } \\
\text { (ChlA, StmA ) }\end{array}$ \\
\hline 1 & $\begin{array}{l}\text { Chlorine } \\
\text { Steamer }\end{array}$ & $\begin{array}{l}1.40 \pm 0.22 \mathrm{a} \\
1.63 \pm 0.30 \mathrm{a}\end{array}$ & $\begin{array}{l}1.33 \pm 0.14 \mathrm{a} \\
1.00 \pm 0.18 \mathrm{a}\end{array}$ & $\begin{array}{l}1.26 \pm 0.10 \mathrm{a} \\
1.00 \pm 0.14 \mathrm{a}\end{array}$ & $\begin{array}{l}1.40 \pm 0.20 \mathrm{a} \\
1.12 \pm 0.27 \mathrm{a}\end{array}$ \\
\hline 5 & $\begin{array}{l}\text { Chlorine } \\
\text { Steamer }\end{array}$ & $\begin{array}{l}2.00 \pm 0.22 b \\
2.40 \pm 0.27 b\end{array}$ & $\begin{array}{l}1.69 \pm 0.14 b \\
1.87 \pm 0.18 b\end{array}$ & $\begin{array}{l}2.46 \pm 0.12 \mathrm{c} \\
2.00 \pm 0.14 \mathrm{~b}\end{array}$ & $\begin{array}{l}1.77 \pm 0.22 b \\
2.37 \pm 0.27 b\end{array}$ \\
\hline 10 & $\begin{array}{l}\text { Chlorine } \\
\text { Steamer }\end{array}$ & $\begin{array}{l}3.57 \pm 0.19 \mathrm{c} \\
3.00 \pm 0.3 \mathrm{c}\end{array}$ & $\begin{array}{l}3.07 \pm 0.14 \mathrm{~d} \\
2.32 \pm 0.19 \mathrm{c}\end{array}$ & $\begin{array}{l}3.24 \pm 0.10 \mathrm{~d} \\
2.14 \pm 0.15 \mathrm{bc}\end{array}$ & $\begin{array}{l}3.35 \pm 0.21 \mathrm{c} \\
3.00 \pm 0.27 \mathrm{c}\end{array}$ \\
\hline
\end{tabular}

Each value represents mean and standard deviation. Values followed by different letters in the same row indicate significant differences during storage. Upper case letters indicate differences between treatments (chlorine-Chl-/steamer-Stm). Three replicates per treatment and per batch were analysed.

tate combined with heat-shock maintained the textural properties of fresh-cut lettuce during storage (Martin-Diana et al., 2005a, in press) Also, the heat treatment might have expanded the air within the lettuce tissues, and the subsequent cooling and contraction of this air would have absorbed the surrounding water into the lettuce, therefore keeping better the moisture and turgor of the lettuce.

\subsubsection{Sensory analysis}

The fresh appearance, browning and acceptability are key aspects used in sensorial analysis to evaluate the general quality of a product. This is especially true for lettuce where browning is a critical factor in the perceived loss of quality.

The blanching at the dose used in the present study had no significant effects $(\mathrm{p}<0.05)$ on the initial (day 1$)$ sensory attributes of fresh-cut lettuce samples compared with chlorinated samples (Table 3). Panellists gave similar scores for both blanched and chlorinated samples, which indicated that all were highly acceptable as judged by appearance, acceptability and browning. Moreover, blanched and chlorinated samples gave similar acceptability scores for the sensory attributes during refrigerated storage until the rejection at day 10 .

Scores of fresh appearance and general acceptability showed a significant $(\mathrm{p}<0.05)$ decrease over the storage, meanwhile browning (photosynthetic and vascular) increased significantly, as expected, with no differences between treatments.

\subsection{Safety markers}

\subsubsection{Mesophiles}

The effect of the steamer and chlorine (120 mg L-1) washing treatments on the mesophilic load of packaged fresh-cut lettuce was monitored over 10-day storage at $4 \circ \mathrm{C}$. The two large outer leaves of the lettuce heads were discarded and only the top part of the head was used in order to minimise the variability between batches and numerous factors such as ambient conditions during harvest, the presence of soil accompanying the product or post-harvest handling, etc. (Ponce et al., 2002). Initial values in non-treated samples were higher, with values ranging $\sim 109$ CFU kg-1, than previous reports or studies reported by other authors $(\sim 108 \mathrm{CFU} \mathrm{kg}-1)$ (Rico et al., 2007a, 2006; Ponce et al., 2002). Perhaps the high temperature during the summer in Spain compared with previous experiences in Ireland favoured these higher microbial loads. Chlorine and the steamer produced a significantly $(\mathrm{p}<0.05)$ reduction in the $\mathrm{CFU}(\sim 1.8 \log )$ with respect to the water $(1 \log$ reduction).

A similar increase in microbial load was observed the samples treated with chlorine and the steamer. No differences between treatments were found at the end of storage (day 10). The values at the end of storage were within the limit recommended (1011 CFU kg-1) for consumer consumption (Debevere, 1996).
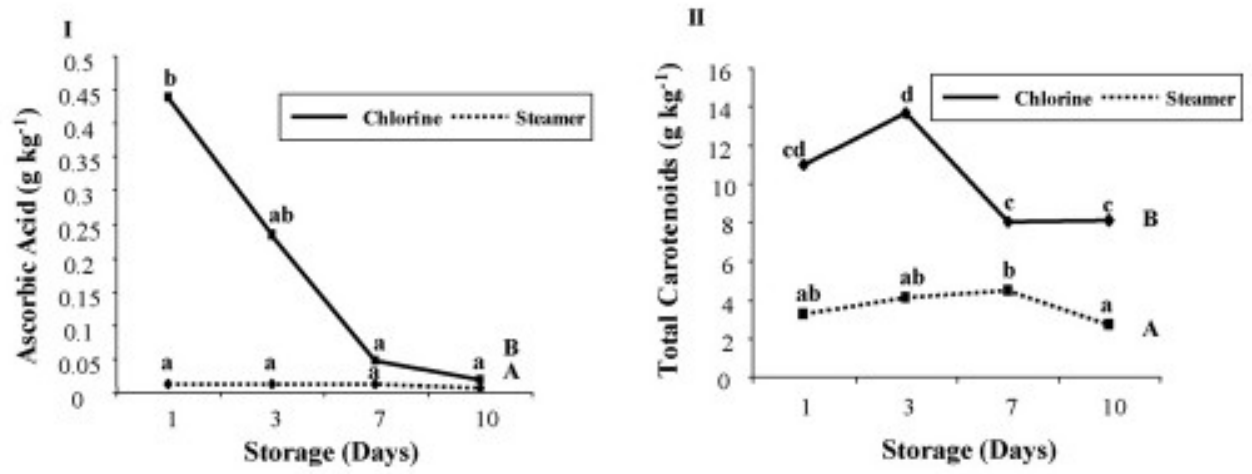

Fig. 8. Effect of steamer and chlorine on the vitamin $\mathrm{C}(\mathrm{g} \mathrm{kg}-1)$ and carotenoids $(\mathrm{g} \mathrm{kg}-1)$ of fresh-cut lettuce treated with chlorine and for steamer and stored for 10 days at $4 \cdot \mathrm{C}$. * Points designated on any curve by the same letter are not significantly different $(\mathrm{p}>0.05)$. Lower case letters are used for comparisons during storage and upper case letters for treatment comparisons. Three independent trials were carried out. Three replicates per treatment and per batch were analysed. 


\subsection{Antioxidant markers}

\subsubsection{Ascorbic acid and carotenoids}

These compounds were measured as two potent antioxidants in fresh-cut lettuce. Ascorbic acid was monitored during the 10 days, in samples treated with chlorine and samples treated with steam. Significantly higher values were found in chlorinated samples (Fig. 8I) throughout storage. Blanching caused a significant decrease in vitamin $\mathrm{C}$ content, which could be attributed to the fact the vitamin $\mathrm{C}$ is very soluble in water and not stable at high temperature (Nagy and Smooth, 1976; Liu et al., 2002).

Chlorine-washed samples showed a decrease in the levels of ascorbic acid during storage, decrease was not observed in steamer-exposed samples since the ascorbic acid levels were close to zero during storage.

Fig. 8II shows total carotenoid concentration of the freshcut lettuce treated with the steamer or chlorine. Significant differences $(p<0.05)$ were observed between treatments. Chlorine-treated samples maintained carotenoid levels of $\sim 13 \mathrm{~g} \mathrm{~kg}-1$ throughout storage, meanwhile lettuce exposed to steam showed carotenoid concentration of approximately a third of this level. Both samples showed a significant decrease in carotenoid concentration over storage.

\section{Conclusions}

Quality parameters, such as browning appearance and improved textural properties, were better maintained by the steam treatment in fresh-cut lettuce compared with the standard chlorine treatment. From a safety point of view, microbial levels were maintained at similar levels by both treatments and considered acceptable for consumption at the end of the storage (10 days). However, a negative effect was observed in the use of steam, which resulted in a significant reduction of the antioxidant levels, especially in ascorbic acid levels, which is highly sensitive to high temperatures, and to a lower extend the steam treatment also affected the carotenoid levels. Sensory panel scored similar general acceptability and fresh appearance values for both treatments. The steamer method has the advantage of avoiding the use of chlorine and therefore the associated formation of carcinogenic chlorinated compounds in water (chloramines and trihalomethanes) which has brought in to debate the use of chlorine. For this reason the loss of ascorbic acid could be supplied with an incorporation of an external source of vitamin $\mathrm{C}$ using atomizing (spray) techniques after the decontamination treatments. A compromise must be reached between palatability (quality), safety and nutrition in the final product when using a steamer for fresh-cut lettuce. Further investigations will be necessary in order to optimise the exposure conditions of the produce. of Valencia and Gemma Briz for assistance in the microbial analysis.

\section{References}

Adams, J.B., Harvey, A., Dempsey, C.E., 1996. Regenerated and denatured peroxidase as potential lipid oxidation catalysts. Food Chem. 57 (4), 505-514.

An Bord Glas, 2004. http://www.bordglas.ie/facts/production.html (4 April 2004).

AOAC, 1995. Official Methods of Analysis, 16th edR. Association of Official Analytical Chemists, Washington, DC, p. 690.

Arroqui, C., Lopez, A., Esnoz, A., Virseda, M.P., 2003. Mathematical model of heat transfer and enzyme inactivation in an integrated blancher cooler. $\mathrm{J}$. Food Eng. 58 (3), 215-225.

Arthey, D., Dennis, C., 1992. Procesado de Hortalizas. Zaragoza, Acribia

Bartolome, L.G., Hoff, J.E., 1972. Firming of potatoes: biochemical effect of preheating. J. Agric. Food Chem. 20, 266-270.

Baur, S., Klaiber, R., Wei, H., Hammes, W.P., Carle, R., 2005. Effect of temperature and chlorination of pre-washing water on shelf-life and physiological properties of ready to use iceberg lettuce. Innov. Food Sci. Emerg. Technol. $6,171-182$.

Beuchat, L.R., Brackett, R.E., 1990. Survival and growth of Listeria monocytogenes on lettuce as influenced by shredding, chlorine treatment modified atmosphere packaging and temperature. J. Food Sci. 55 (3), 755 758 .

Brecht, J.K., 1995. Physiology of lightly processed fruits and vegetables. Horticult. Sci. 30, 18-22.

Chang, C.Y., Liao, H.J., Wu, T.P., 1996. Relationships between the textural changes and the contents of calcium, magnesium ions, and non-freezing water in the alcohol-insoluble solids of snap bean pods during cooking processes. Food Chem. 55 (1), 49-53.

Debevere, J., 1996. Voedingsmiddelen en recht 2. Etikettering, houdbaarheid en bewaring. Uitgeverij Die Keure, Brugge, pp. 37-64.

Delaquis, P.J., Stewart, S., Toivonen, P.M.A., Moyls, L.A., 1999. Effect of warm, chlorinated water on the microbial flora of shredded iceberg lettuce. Food Res. Int. 32, 7-14.

Dychdala, G.R., 1991. Chlorine and chlorine compounds. In: Block, S.S. (Ed.), Disinfection, Sterilization, and Preservation, 4th ed. Lea \& Febiger, Philadelphia, PA, pp. 131-151.

G" rtner, U., Mayer-Miebach, E., Spiess, W.E.L., 1997. Controlling the micro-a bial load on ready-to-use sliced salads by low-temperature blanching. In: Jowitt, R. (Ed.), Engineering and Food at ICEF 7. Sheffield Academic Press, Sheffield, pp. J41-J42.

Galeazzi, M.A.M., Sgarbieri, V.C., Constantinides, S.M., 1981. Isolation, purification and physicochemical characterization of polyphenoloxidase (PPO) from dwarf variety of banana (Musa cavendishii, L). J. Food Sci. 46, $150-155$.

Garcia, J.M., Herrera, S., Morilla, A., 1996. Effects of postharvest dips in calcium chloride on strawberry. J. Agric. Food Chem. 44, 30-33.

Gross, J., 1991. Carotenoids. In: Pigments in Vegetables: Chlorophyllase and Carotenoids. Van Nostrand Reinhold, New York, pp. 124-128.

Heimdal, H., Larsen, L.L., Poll, L., 1994. Characterization of polyphenol oxidase from photosynthetic and vascular lettuce tissues (Lactuca sativa). J. Agric. Food Chem. 42, 1428-1433.

Ihl, M., Aravena, L., Ssheuermann, E., Uquiche, E., Bifani, V., 2003. Effect of immersion solutions on shelf-life of minimally processed lettuce. Food Sci. Technol. 36, 591-599.

Kays, S.J., 1991. Postharvest Physiology of Perishable Plant Products. Van Nostrand Reinhold, New York.

Lee, S.K., Kader, A.A., 2000. Preharvest and postharvest factors influencing vitamin C content of horticultural crops. Postharvest Biol. Technol. 20, 207-220.

Liu, R.F., Dewanto, V., Wu, X., Adom, K. 2002. Effect of thermal processing on the nutritional values of tomatoes. http://ift.confex.com ift/2002/techprogram/paper 14046.html.

McKellar, R.C., Odumeru, J., Zhou, T., Harrison, A.D., Mercer, D.G., Young, J.C., Lu, X., Boulter, J., Piyasena, P., Karr, S., 2004. Influence of a com-

\section{Acknowledgements}

This research was supported by a Technological Sector Research grant (2002-2006) and International Collaboration Award Scheme (ICAS) (2005-2007). The authors would like to thank the laboratory facilities service at University Politicnicae 
mercial warm chlorinated water treatment and packaging on the shelf-life of ready-to-use lettuce. Food Res. Int. 37, 343-354.

Martin-Diana, A.B., Rico, D., Barry-Ryan, C., Frias, J.M., Mulcahy, J., Henehan, G.T.M., 2005a. Effect of calcium lactate concentration and temperature washing treatments on quality retention of salad-cut Iceberg lettuce. Food Res Int. 38, 729-740.

Martin-Diana, A.B., Rico, D., Barry-Ryan, C., Mulcahy, J., Frias, J.M., Henehan, G.T.M., 2005b. Effect of heat-shock on browning-related enzymes in minimally processed Iceberg lettuce and crude extracts. Biosci. Biotechnol. Biochem. 69 (8), 213-219.

Martin-Diana, A.B., Rico, D., Frias, J., Henehan, G.T.M., Mulcahy, J., Barat, J.M., Barry-Ryan, C., in press. Effect of calcium lactate and heat-shock on texture in fresh-cut lettuce during storage. J. Food Eng.

Nagy, S., Smooth, J.M., 1976. Temperature and storage effects on percent retention and percent U.S. recommended dietary allowances of vitamin C in canned single-strength orange juice. J. Agric. Food Chem. 25 (1), 135-138.

Negi, P.S., Roy, S.K., 2000. Effect of blanching and drying methods on betacarotene, ascorbic acid and chlorophyll retention of leafy vegetables. Food Sci. Technol. 33, 295-298.

Ni, L., Lin, D., Barret, M.D., 2005. Pectin methylesterase catalyzed firming effects on low temperature blanched vegetables. J. Food Eng. 70, 546-556.

Odumeru, J.A., Boulter, J., Knight, K., Lu, X., McKellar, R.C., 2003. Assessment of a wash treatment with warm chlorinated water to extend the shelf-life of ready-to-use lettuce. J. Food Qual. 26, 197-209.

Page, T., Harris, R.H., Epstein, S.S., 1976. Drinking water and cancer mortality in Louisiana. Science 193, 55-57.

Parish, M.E., Beuchat, L.R., Suslow, T.V., Harris, L.J., Garrett, E.H., Farber, J.N., Busta, F.F., 2001. Methods to reduce/eliminate pathogens from fresh and fresh-cut produce. Institute of food technologist. Analysis and evaluation of preventive control measures for the control and reduction/elimination of microbial hazards on fresh and fresh-cut produce. Compr. Rev. Food Sci. Food Safety 2 (1), 161-173.

Ponce, A.G., Roura, S.I., Del Valle, C.E., Fritz, R., 2002. Characterization of native microbial population of Swiss Chard (Beta vulgaris, type cicla). LWT 35 (4), 331-337.

Rico, D., Martin-Diana, A.B., Henehan, G.T.M., Frias, J., Barat, J.M., BarryRyan, C., 2007a. Improvement in texture using calcium lactate and heat- shock treatments for stored ready-to-eat carrots. J. Food Eng., submitted for publication.

Rico, D., Martin-Diana, A.B., Henehan, G.T.M., Frias, J., Barry-Ryan, C., 2006. Effect of Ozone and Calcium Lactate treatments on browning and textured properties of fresh-cut lettuce. J. Food Sci. Agr. 77, 1069-1077.

Rico, D., Martin-Diana, A.B., Barry-Ryan, C., Fr'as, J.M., Henehan, G.T.M.,1 Barat, J.M., 2007b. Application of response surface methodology for the optimisation of the use of steamer jet-injection in extending the shelf-life of fresh-cut lettuce. J. Food Eng., submitted for publication.

Rodrigo, C., Rodrigo, M., Alvarruiz, A., Frigola, A., 1997. Inactivation and regeneration kinetics of horseradish peroxidase heated at high temperatures. J. Food Protec. 60 (8), 961-966.

Ryall, A.L., Lipton, W.J., 1972. Handling, Transportation and Storage of Fruit and Vegetables, vol. 1. AVI Pub. Co., Westport, CN.

Saltveit, M.E., 2000. Wound induced changes in phenolic metabolism and tissue browning are altered by heat shock. Postharvest Biol. Technol. 21, 6169.

Sam, C.E., 1999. Preharvest factors affecting postharvest texture. Postharvest Biol. Technol. 15, 249-254.

Song, J.Y., An, G.H., Kim, C.J., 2003. Color, texture, nutrient contents, and sensory values of vegetable soybeans [Glycine max (L.) Merrill] as affected by blanching. Food Chem. 83 (1), 69-74.

Surjadinata, B.B., Cisneros-Zevallos, L., 2003. Modeling wound-induced respiration of fresh-cut carrots (Daucus carots L.). J. Food Sci. 68, 2735-2740.

Tan, B.K., Harris, N.D., 1995. Maillard products inhibit apple polyphenoxidase. Food Chem. 53, 267-273

Vamos-Vigyazo, L., 1981. Polyphenol oxidase and peroxidase in fruits and vegetables. Crit. Rev. Food Sci. Nutr. 15, 49-127.

Van Buren, J.P., 1979. The chemistry of texture in fruits and vegetables. J. Texture Stud. 10, 1-23.

Vi`a, S.Z., Chaves, A.S., 2006. Antioxidant responses in minimally processedn celery during refrigerated storage. Food Chem. 94, 68-74.

Watada, A.E., Qui, L., 1999. Quality of fresh-cut produce. Postharvest Biol. Technol. 15, 201-205.

Wei, C.I., Huang, T.S., Kim, J.M., Lin, W.F., Tamplin, M.L., Bartz, J.A., 1995. Growth and survival of Salmonella montevideo on tomatoes and disinfection with chlorinated water. J. Food Protect. 58, 829-836. 